\title{
Planetary Boundary Layer Heights from Cruises in Spring to Autumn Chukchi-Beaufort Sea Compared with ERA5
}

\author{
Mingyi Gu ${ }^{1,2} \mathbb{D}$, G. W. K. Moore ${ }^{2, *}$, Kevin Wood ${ }^{3}$ and Zhaomin Wang ${ }^{4,5, *}$ \\ 1 School of Atmospheric Sciences, Nanjing University of Information Science and Technology, \\ Nanjing 210044, China; mingyi.gu@mail.utoronto.ca \\ 2 Department of Physics, University of Toronto, Toronto, ON L5L 1C6, Canada \\ 3 NOAA Pacific Marine Environmental Laboratory, Joint Institute for the Study of the Atmosphere and \\ Ocean (JISAO), University of Washington, Seattle, WA 98115, USA; kevin.r.wood@noaa.gov \\ 4 Key Laboratory of Marine Hazards Forecasting, Ministry of Natural Resources, Hohai University, \\ Nanjing 210024, China \\ 5 Southern Marine Science and Engineering Guangdong Laboratory (Zhuhai), Zhuhai 519082, China \\ * Correspondence: gwk.moore@utoronto.ca (G.W.K.M.); zhaomin.wang@hhu.edu.cn (Z.W.)
}

check for updates

Citation: Gu, M.; Moore, G.W.K.; Wood, K.; Wang, Z. Planetary Boundary Layer Heights from Cruises in Spring to Autumn Chukchi-Beaufort Sea Compared with ERA5. Atmosphere 2021, 12, 1398. https://doi.org/10.3390/ atmos12111398

Academic Editors: Qiusheng Li, Junyi He and Bin Lu

Received: 4 September 2021 Accepted: 20 October 2021 Published: 25 October 2021

Publisher's Note: MDPI stays neutral with regard to jurisdictional claims in published maps and institutional affiliations.

Copyright: (C) 2021 by the authors. Licensee MDPI, Basel, Switzerland. This article is an open access article distributed under the terms and conditions of the Creative Commons Attribution (CC BY) license (https:/ / creativecommons.org/licenses/by/ $4.0 /)$.

\begin{abstract}
The planetary boundary layer height (PBLH) is a diagnostic field related to the effective heat capacity of the lower atmosphere, both stable and convective, and it constrains motion in this layer as well as impacts surface warming. Here, we used radiosonde data from five icebreaker cruises to the Chukchi and Beaufort Seas during both spring and fall to derive PBLH using the bulk Ri method, which were then compared with results from ERA5 reanalysis. The ERA5 PBLH was similar to but slightly lower than the ship observations. Clear and consistent seasonal changes were found in both the observations and the reanalysis: PBLH decreased from mid-May to mid-June and subsequently increased after August. The comparison with ERA5 shows that, besides surface temperature, biases in PBLH are also a function of wind direction, suggesting that the availability of upwind observations is also important in representing processes active in the boundary layer over the Arctic Ocean.
\end{abstract}

Keywords: planetary boundary layer heights comparison; icebreaker cruises dataset; Chukchi and Beaufort Seas

\section{Introduction}

The Arctic has experienced a rapid warming since the 1980s in a so-called Arctic Amplification [1-5], and the rate of surface warming is more than twice that of the entire globe [6-9]. The planetary boundary layer (PBL) plays an important role in air-surface interactions and impacts the rate of surface warming. In addition to the retreat of sea ice [10], increased water vapor [11], increased poleward energy transport [12], and lapserate feedback [13], the Arctic surface warming has also been attributed to the typically shallow boundary layer in the Arctic, as a shallow boundary layer acts to amplify any surface warming [14-16].

The PBL height (PBLH) has been recognized as an important parameter in quantifying the role of boundary layer processes in surface processes. PBLH is closely related to the effective heat capacity of the atmosphere, both stable and convective [16], and is a primary determinant of cloud type and coverage that impacts the Earth's radiation budget [17,18]. PBLH varies under different climate forcing; therefore, it is critical to gain an understanding of the spatiotemporal variability of the PBLH, especially in the Arctic [19,20]. It remains a challenge to parameterize the physical and chemical PBL processes in the global climate models, as these models do not resolve the shallow boundary layer [21]. There is evidence that the PBLH in both numerical weather prediction and climate models is generally higher than the observations, especially in the cases of stable conditions [21,22]. Over the central Arctic Ocean, the boundary layer usually has near-neutral stability in the summer $[23,24]$. 
During the winter, the absence of solar radiation allows for the formation of a persistent stable boundary layer during cloud-free periods, while low-level clouds tend to force a shallow but relatively well-mixed boundary layer [23,25]. This unique characteristic makes it important to study the Arctic PBL and its role in Arctic Amplification.

The recent studies on Arctic PBL focus mainly on the interactions with clouds [26-28] and sea ice [29]. Limited studies have attempted to derive the PBLH using climatological mean state [30] and aircraft and GPS soundings observations [31]. The Arctic is a remote, sparsely populated region with very limited infrastructure and accessibility [16] to observe atmospheric processes. As a result, there are very limited data as to the structure and temporal evolution of the PBL over the Arctic Ocean. The Surface Heat Budget of the Arctic Ocean experiment (SHEBA), which was conducted with a drifting icebreaker over multiyear ice in the Beaufort Sea 1997-1998 [23], has contributed to knowledge on the surface processes in the Arctic, including: examining different regimes of the stable boundary layer [32] and exploring a PBLH calculation method [33], as well as characterizing the diurnal cycle of PBLH [34]. Some other data, such as "North Pole" drifting ice stations [35], the Arctic Ocean Climate System Research observed on R/V Mirai [36,37], and the ASCOS measurement campaign observed on the Swedish icebreaker Oden in the summer of 2008 [25,38], have been helpful in studying boundary layer processes [39]. However, the lack of observations over space and time has limited our ability to understand the processes that determine the height of the planetary boundary layer. Here, we help address this gap by using the recently released Chukchi-Beaufort icebreaker cruises' radiosonde data to study Arctic PBLH, and we also use a new reanalysis dataset, ERA5, to examine the processes in the Arctic PBL.

\section{Materials and Methods}

In this paper, radiosonde data from five icebreaker cruises to the Chukchi and Beaufort Seas were used. We named these cruises by the research vessel name and corresponding year of observation. Data are available from both the late spring (May-June) as well as the early fall (August-October). In total, 373 individual radiosonde ascents were used in this work (39 ascents in Louis 2013, from 6 August to 31 August; 76 ascents in Healy 2014, from 17 May to 20 June; 183 ascents in Mirai 2014, from 5 September to 28 September; 38 ascents in Louis 2014, from 26 September to 15 October; and 37 ascents in Louis 2015, from 24 September to 12 October, see Tables S1-S5 for details). The locations and mean sea ice concentrations of the observations are shown in Figure 1.
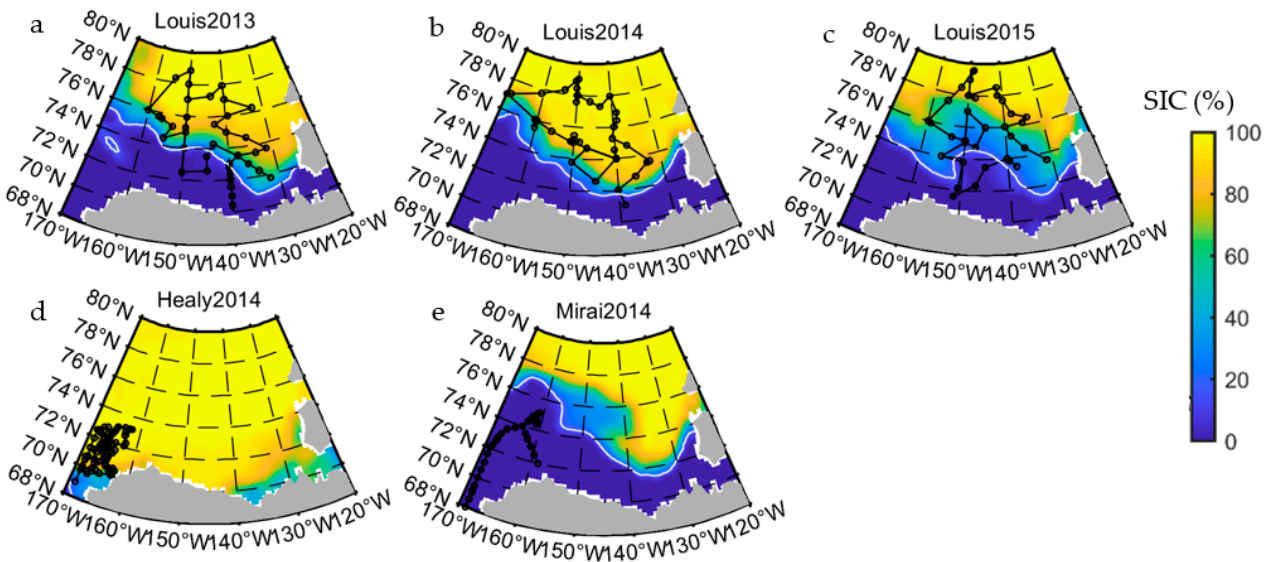

Figure 1. Cruise routes and mean sea ice concentration (SIC, \%) during Louis 2013 ((a), from 6 August to 31 August), Louis 2014 ((b), from 26 September to 15 October), Louis 2015 ((c), from 24 September to 12 October), Healy 2014 ((d), from 17 May to 20 June) and Mirai 2014 ((e), from 5 September to 28 September). Each circle with line linking shows the location of each observation along the cruise. The base colors in shading show the mean ERA5 sea ice concentration during each cruise, while the white solid line represents the $15 \%$ sea ice concentration isogram. 
We used the radiosonde data to diagnose the "observed" PBLH. Seidel [22] tested several methods and found out that the bulk $R i$ method is the most suitable for diagnosing PBLH, as it is suitable for both stable and convective boundary layers and is not strongly dependent on vertical resolution. The "observed" PBLH was found by searching upwards from the lowest observation, with the PBLH defined as that level where the Ri equals the critical value of 0.25 . The $R i$ at level $\mathrm{k}$ is calculated by:

$$
\begin{aligned}
& R i=z_{k} \frac{2 g\left(s_{v k}-s_{v s}\right)}{\left[\left(U_{k}-U_{s}\right)^{2}+\left(V_{k}-V_{s}\right)^{2}\right]\left(s_{v k}+s_{v s}-g z_{k}-g z_{s}\right)} \\
& \text { where }_{v k}=c_{p} T_{k}\left(1+\varepsilon q_{k}\right)+g z_{k}, s_{v s}=c_{p} T_{s}\left(1+\varepsilon q_{s}\right)+g z_{s} \text {, and } \varepsilon=\frac{R_{v a p}}{R_{d r y}}-1 \text {, }
\end{aligned}
$$

where $z$ is the height, $g$ is the acceleration of gravity, $S_{v}$ is the virtual dry static energy, $U$ and $V$ are zonal and meridional wind components, $c_{p}$ is the specific heat at constant pressure of moist air, $T$ is temperature, $\varepsilon$ is parcel entrainment $\left(R_{\text {vap }}\right.$ and $R_{d r y}$ are the gas constant for water vapor and for dry air, respectively), $q$ is specific humidity, and the subscript $\mathrm{k}$ and $\mathrm{s}$ represent the level and the surface (lowest level in observation), respectively. Here, we set $g$ as $9.8 \mathrm{~m} \mathrm{~s}^{-2}, U_{S}$ and $V_{S}$ as zero, $\mathrm{c}_{\mathrm{p}}$ as $1004.7 \mathrm{~J} \mathrm{~kg}^{-1} \mathrm{~K}^{-1}, \varepsilon$ as 0.61 . If the $R i$ at level $\mathrm{k}$ is larger than 0.25 and the $R i$ at level $(\mathrm{k}-1)$ is smaller than 0.25 , the PBLH will be linearly interpolated by $R i$ from the heights at level $\mathrm{k}$ and $(\mathrm{k}-1)$.

ERA5 is the newest global reanalysis produced by ECMWF [39]. ERA5 has hourly output throughout, $31 \mathrm{~km}$ horizontal resolution, and 137 vertical levels from the surface up to a height of $80 \mathrm{~km}$. There are already some works showing that ERA5 performs better than some other reanalysis in the Arctic [40,41]. Here, ERA5 hourly PBLH, 2-meter temperature, 100-meter $U$ and $V$, and sea surface pressure are used in this paper.

$R i$ for radiosondes is calculated using the same method as in ERA5 (ECMWF. IFS CY41R2 Part IV, content 3.10.1, Formula 3.90, https: / / www.ecmwf.int/ node/16648, accessed on 19 October 2021). To assist in the calculation, the ERA5 data were linearly interpolated to the locations of the radiosonde data. To compare the wind components, $U$ and $V$ in radiosonde data were linearly interpolated to a $100 \mathrm{~m}$ height.

\section{Results}

The observed PBLH of each cruise, as well as the lowest temperature, are shown in Figure 2, and the mean values and other parameters of observed and ERA5 PBLH are listed in Table 1. As shown in Table 1, the mean of observed PBLH is $488 \mathrm{~m}$, and the standard deviation (STD) is $254 \mathrm{~m}$. The mean of ERA5 PBLH after interpolation is $485 \mathrm{~m}$, and the STD is $226 \mathrm{~m}$. However, the root-mean-square error (RMSE) between ERA5 and observed PBLH is $201 \mathrm{~m}$ averaged over all the cruises and varied from $143 \mathrm{~m}$ for cruise Mirai 2014 to $345 \mathrm{~m}$ for cruise Louis 2014 (Table 1), indicating some large differences at individual locations.

\begin{tabular}{|c|c|c|c|c|c|}
\hline Period & $\begin{array}{l}\text { ERA5 Mean } \\
\text { (STD), m (m) }\end{array}$ & $\begin{array}{l}\text { Observation Mean (STD), } \\
\text { m (m) }\end{array}$ & $\begin{array}{l}\text { Correlation } \\
\text { Coefficient }\end{array}$ & RMSE, m & Bias Error, $\mathrm{m}$ \\
\hline Total & $485(226)$ & $488(254)$ & 0.63 & 207 & -3 \\
\hline Louis 2013 & $248(160)$ & $316(248)$ & 0.36 & 251 & -68 \\
\hline Louis 2014 & $353(191)$ & $562(313)$ & 0.49 & 345 & -209 \\
\hline Louis 2015 & 499 (226) & $501(195)$ & 0.73 & 157 & -2 \\
\hline Mirai 2014 & 577 (197) & $512(224)$ & 0.82 & 143 & 65 \\
\hline Healy 2014 & $446(205)$ & $476(277)$ & 0.55 & 238 & -30 \\
\hline Healy 2014 (cold) & $520(237)$ & $569(322)$ & 0.50 & 292 & -49 \\
\hline Healy 2014 (warm) & $368(123)$ & $378(171)$ & 0.43 & 162 & -10 \\
\hline
\end{tabular}

Table 1. Mean PBLH (m) from ERA5 and each cruise. 

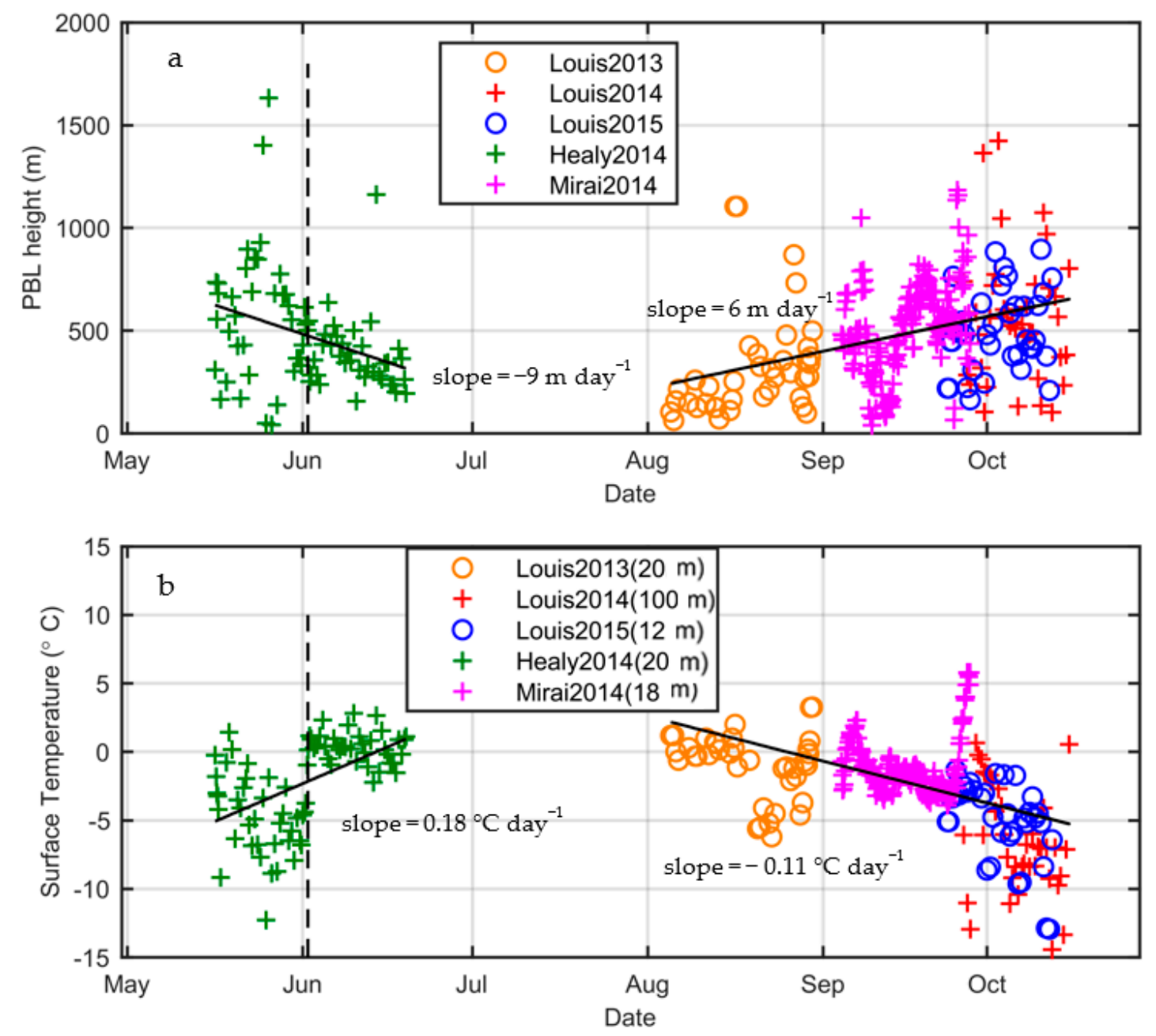

Figure 2. Planetary boundary layer heights (a) and the lowest level temperature (b) obtained from the radiosonde data of the cruises. The straight lines are the least squares fits for early summer and early autumn, and the slope has been displayed adjacently. The lowest level heights (the first heights from GPS reported) are labeled correspondingly. The vertical dashed lines divide Healy 2014 into a cold and warm period.

The seasonal variations in PBLH are evident for the observational results (Figure 2a) and for the ERA5 results (Figure 3a). In the period of the observations, PBLH decreased from mid-May $(\sim 570 \mathrm{~m})$ to mid-June $(\sim 280 \mathrm{~m})$ and increased after August $(\sim 150 \mathrm{~m})$ to October $(\sim 570 \mathrm{~m})$, which is opposite to the variation of air temperature at the lowest levels (defined as surface air temperature in this study, and for ERA5, 2-meter temperatures were used) (Figures $2 b$ and $3 b$ ). This seasonal variation of PBLH is roughly consistent with the previous study using the aircraft and GPS soundings in SHEBA [31]. The storm events were found to be more numerous [42] and more intense [43] in winter than in summer over Chukchi-Beaufort Sea, which might contribute to the observed and modeled seasonal variability in PBLH. 

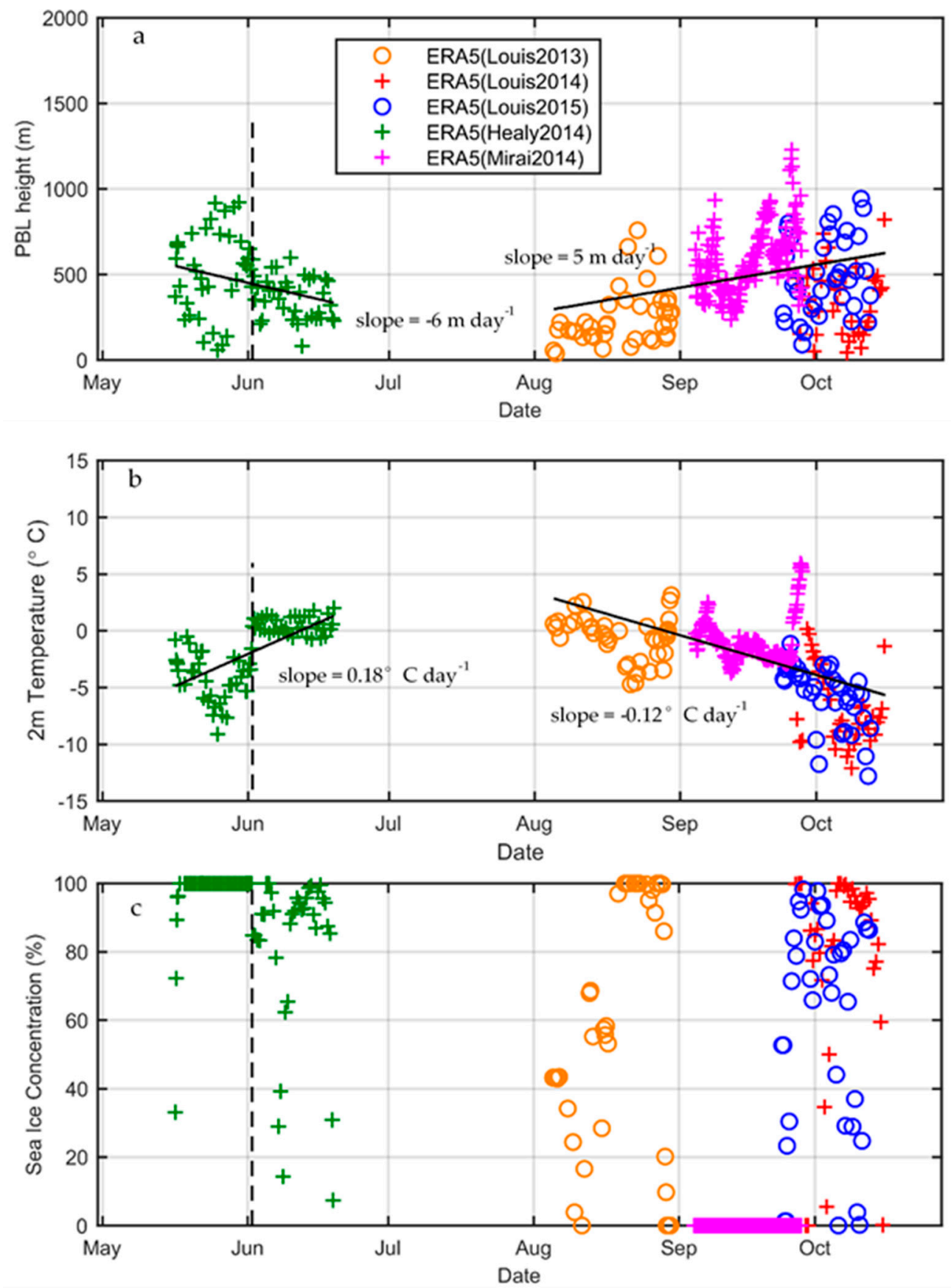

Figure 3. Same as Figure 2, but for ERA5 planetary boundary layer heights (a), 2-meter temperature (b), and sea ice concentration (c).

To elucidate the impact of surface air temperatures on the PBLH, we consider the case of the Healy 2014 cruise, during which there was a marked transition from cold $\left(\sim-4{ }^{\circ} \mathrm{C}\right)$ to warm $\left(\sim 0.4^{\circ} \mathrm{C}\right)$ conditions (Figure 4$)$. The time series of ERA5 sea ice concentration are shown in Figure $3 \mathrm{c}$ and are consistent with the temperature transition. This transition occurred on 2 June 2014, and we use this date to divide the cruise period into a cold and warm period. For the entire Healy period, the average observed PLBH is $475.7 \mathrm{~m}$, and the RMSE between ERA5 and observed PBLH is $237.8 \mathrm{~m}$. The mean PBLH for the cold period $(568.8 \pm 321.7 \mathrm{~m})$ is much larger than that for the warm period $(377.7 \pm 170.8 \mathrm{~m})$. The ERA5 PBLH are slightly lower than the observations but also show this clear shift $(519.8 \pm 321.7 \mathrm{~m}$ for the cold period and $367.5 \pm 122.6 \mathrm{~m}$ for the warm period). The bias error of ERA5 in the cold period is $-49.0 \mathrm{~m}$ and in the warm period is $-10.1 \mathrm{~m}$, and 
the RMSEs between ERA5 and observations are $292.2 \mathrm{~m}$ and $161.8 \mathrm{~m}$, respectively. With comparison among these results in Table 1, except Mirai 2014, it can be concluded that the higher PBLH are, the higher variances and the higher simulated errors will be.
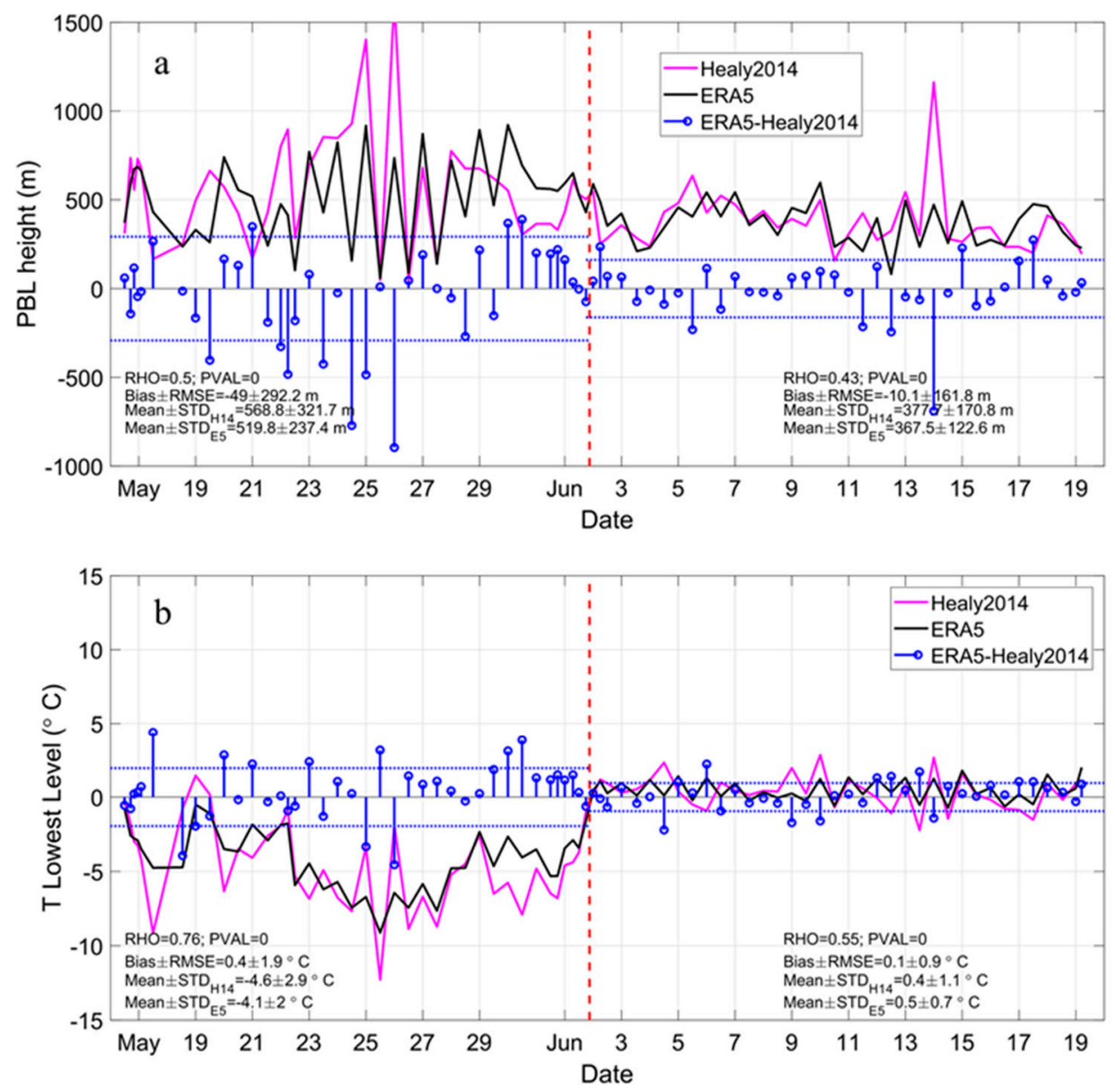

Figure 4. Planetary boundary layer heights (a) and the lowest level temperature (b) obtained from Healy 2014 (magenta lines) and ERA5 (black lines) data. The ball-and-sticks are the differences between the ERA5 and the observation. The horizontal dashed lines represent RMSE between ERA5 and observation in each period. The vertical dashed line divides the whole time into the cold period (information listed left) and the warm period (information listed right). RHO is the correlation coefficient; PVAL is the corresponding p-value which indicates the significance level of the hypothesis that no correlation exists; Bias is bias error; and RMSE is root-mean-square error.

To understand the synoptic conditions that gave rise to this transition, we consider the surface flow as represented in ERA5 over the region of interest during the cold and warm periods (Figure 5). During the cold period, corresponding to the high PBLH and the large bias between the observations and ERA5, the Healy was situated to the east of a region of high pressure, with northerly winds being dominant. In contrast, during the warm period, corresponding to low PBLH and the small bias, the Healy was situated to the west of a region of high pressure, with southerly winds being dominant.

The Healy observations suggest that there may be a relationship between the bias error in PBLH and the direction of the meridional wind, as well as surface temperature (Figure 5). To test this hypothesis, we used the entire database and stratified the results by wind component and temperature (Figure 6). We used ERA5 100-meter winds here in order to be consistent with the following comparisons, because the heights of lowest level in different cruises are different and higher than $10 \mathrm{~m}$. We picked the calendar time of composite analysis by the PBLH differences between ERA5 and observations, whether 
positive and greater than 1 STD or negative and greater than -1 STD. The results were subtracted out from the long mean for the period of interest (1979 to 2018) to avoid the seasonal and diurnal differences.

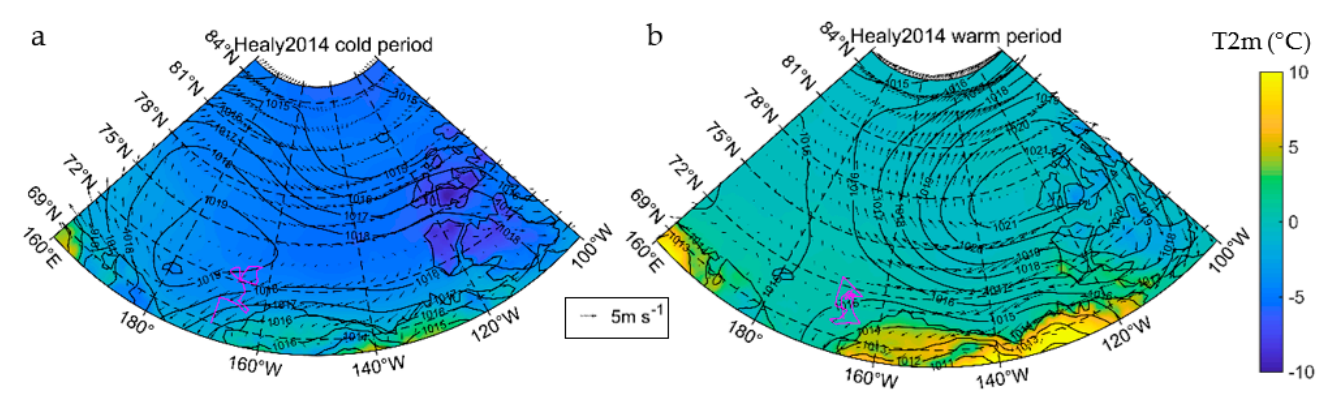

Figure 5. Period average of temperature $\left({ }^{\circ} \mathrm{C}\right.$, shaded color), sea level pressure (hPa, contour), and winds ( $\mathrm{m} \mathrm{s}^{-1}$, arrow) in the Healy 2014 cold period (a) and warm period (b) The purple lines show the locations of the observations in each period.

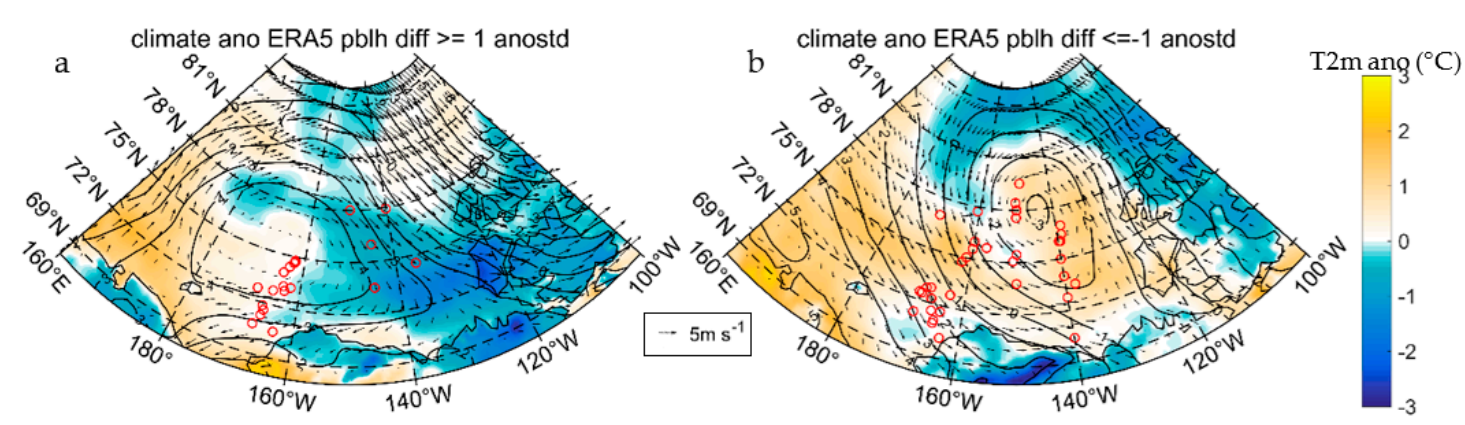

Figure 6. Anomalies of temperature (shading), sea level pressure (contours), and winds (arrows) for the times when ERA5 planetary boundary layer heights had positive biases that were greater than +1 STD (a) and the times when negative biases were greater than -1 STD (values less than -1$)(\mathbf{b})$. The locations of the icebreaker observations with such large biases are marked by red circles.

Consistent with the hypothesis noted above, the large biases mainly occurred when the northerly winds were dominant, independent of whether the bias was positive (Figure 6a) or negative (Figure $6 \mathrm{~b}$ ). ERA5 more likely holds large positive bias of PBLH at the east of the high-pressure anomalies when the high-pressure anomalies are over the Chukchi Sea. Additionally, ERA5 more likely holds large negative biases of PBLH at the southwest of the low-pressure anomalies when the low-pressure anomalies are over the Beaufort Sea.

For further verification of the relationship between the PBLH biases and the northerly winds, we show the dotted points with plus symbols by each variation, and the PBLH differences between ERA5 and observations as coordinates (Figure 7). We divided the 373 observations into six boxes with two black \pm 1 STD lines and one zero line (mean value line for PBLH). We circled large biases of each variation to avoid ERA5 biases in other variations influencing our estimate. According to Figure 7a,b, ERA5 holds huge negative biases when the observed PBLH are large, and huge positive biases when the observed PBLH are small. It is worth noting that the air temperature biases could cause PBLH biases. When ERA5 simulates air temperature lower than the observations, the PBLH in ERA5 is generally lower than the observed PBLH, and vice versa (Figure $7 c, d$ ). The zonal winds have no obvious and consistent influence according to Figure $7 \mathrm{e}, \mathrm{f}$. The number counts in Figure 7g,h show the preponderant and consistent results that more cases of large biases occur under the influences of northerly winds whether the bias is positive or negative, although the huge biases occur in both northerly and southerly winds. 

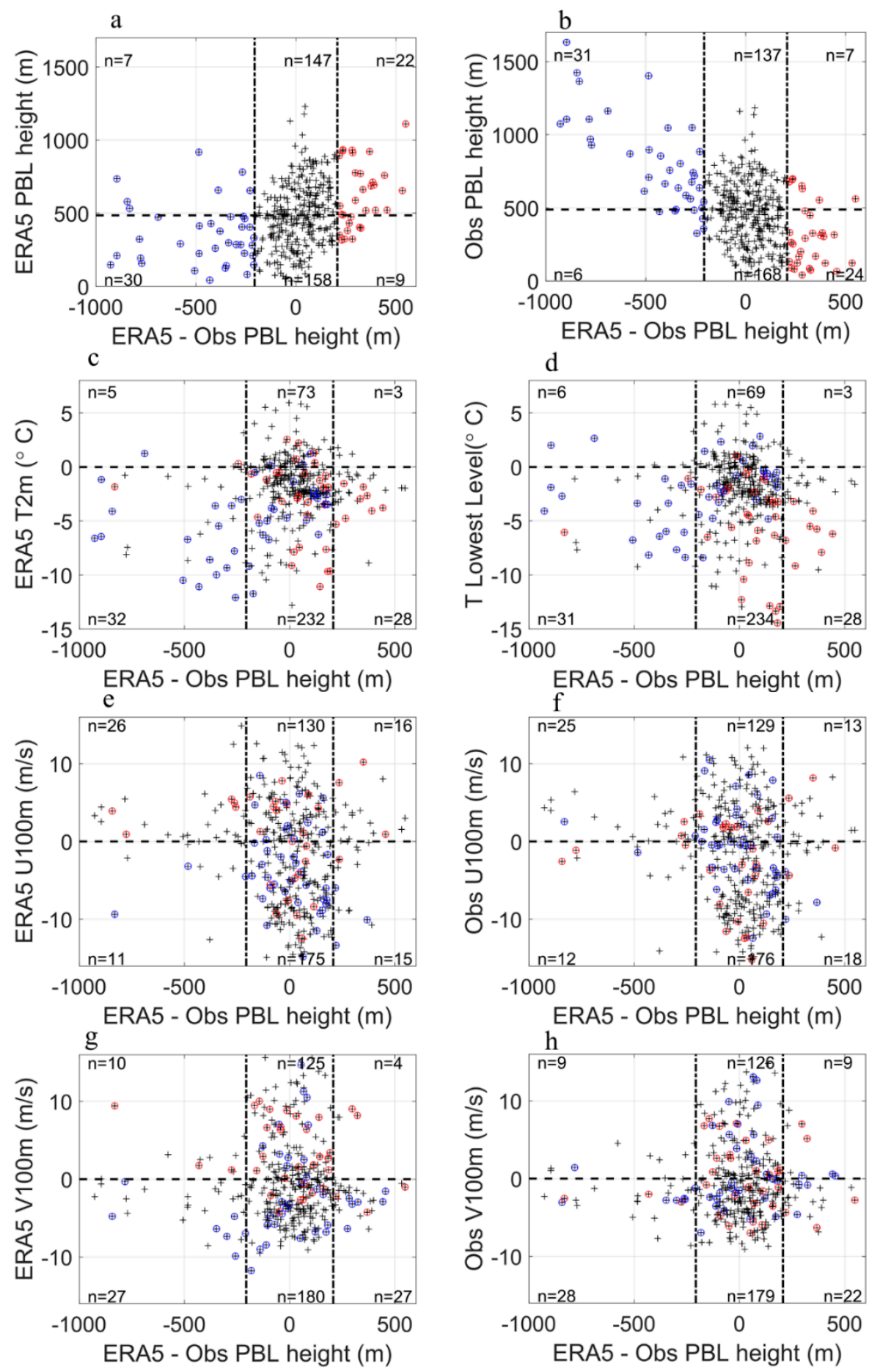

Figure 7. Relationship between ERA5 PBLH bias and ERA5 PBLH (a), observed PBLH (b), ERA5 T2m (c), observed lowest level temperature (d), ERA5 U100m (e), observed U100m (f), ERA5 V100m (g) and observed V100m (h). The black dashed line in $(\mathbf{a}, \mathbf{b})$ is the mean of ERA5 PBLH, while in the other sub-figures, it is zero. The black dash-dotted lines are \pm 1 STD of ERA5 PBLH biases. These black lines divide the observations into six boxes. The blue circles circle these points with large negative ERA5 biases of the variable used in the ordinate, while the red circles circle the points with large positive ERA5 biases.

\section{Discussion and Conclusions}

We analyzed the PBLH of five cruises observed in 2013 2015 from late spring to autumn in the Chukchi-Beaufort Sea and compared them with ERA5 results. It turns out 
that the seasonal variations observed in ERA5 PBLH are evident and parallel. The mean and STD of PBLH derived from observation and from ERA5 both decrease from late spring to the summer and then increase back when it comes to autumn. Esau [30] mentioned some aspects of the seasonal cycle of PBLH. They mainly focus on the climatology of Arctic PBL and they divided the whole Arctic into central Arctic, continental zone, and marine zone but did not separate the ice edge zone individually. For the "central Arctic" region, which included the Chukchi-Beaufort Sea in their work, the PBLH is greatest during summer months. It is the same with the seasonal cycle in continental regions, maybe because the domination of sea ice in central Arctic region makes it more like the continental zone. For the other maritime regions, the PBLH is greatest during winter and spring months when the air-sea temperature difference is greatest. Compared with their work, our results indicate that the seasonal change of PBLH at the ice edge zone is more like the marine zone instead of the continental zone.

Consistent with previous studies $[19,44,45]$, surface temperature might have a significant influence on the magnitude and the variance of PBLH. Surface temperature might also have a significant effect on ERA5 PBLH simulation performance. In our work, when ERA5 simulates air temperature lower than observations, the PBLH in ERA5 is generally lower than the observed PBLH, and vice versa. The Arctic has a limited number of in situ observations. It is also a region where it remains a challenge to assimilate satellite observations into numerical weather prediction models [46]. It follows that the observed bias, when stratified by wind direction, may also be attributed to the fact southerly flow advects information from land-based stations into the region, thereby improving the representation of the PBLH in ERA5 [47,48]. This characteristic may contribute to our finding that large biases of the ERA5 PBLH are more common when there are northerly winds.

Supplementary Materials: The following are available online at https: / www.mdpi.com/article/ $10.3390 /$ atmos12111398/s1. Table S1. The temporal information, location, lowest level height (m) and temperature $\left({ }^{\circ} \mathrm{C}\right)$ at lowest level of Louis2013 used; Table S2. The temporal information, location, lowest level height $(\mathrm{m})$ and temperature $\left({ }^{\circ} \mathrm{C}\right)$ at lowest level of Healy2014 used; Table S3. The temporal information, location, lowest level height $(\mathrm{m})$ and temperature $\left({ }^{\circ} \mathrm{C}\right)$ at lowest level of Mirai2014 used; Table S4. The temporal information, location, lowest level height $(\mathrm{m})$ and temperature $\left({ }^{\circ} \mathrm{C}\right)$ at lowest level of Louis2014 used; Table S5. The temporal information, location, lowest level height $(\mathrm{m})$ and temperature $\left({ }^{\circ} \mathrm{C}\right)$ at lowest level of Louis2015 used.

Author Contributions: Conceptualization, G.W.K.M.; methodology, G.W.K.M.; software, M.G.; validation, K.W.; formal analysis, M.G.; investigation, M.G.; resources, K.W.; data curation, K.W.; writing—original draft preparation, M.G.; writing—review and editing, M.G., G.W.K.M. and Z.W.; visualization, M.G.; supervision, G.W.K.M. and Z.W.; project administration, G.W.K.M. and Z.W.; funding acquisition, G.W.K.M. and Z.W. All authors have read and agreed to the published version of the manuscript.

Funding: This study was supported by the Innovative Platform Program of Chinese Arctic and Antarctic Administration under contract (No.CXPT2020009); Innovation Group Project of Southern Marine Science and Engineering Guangdong Laboratory (Zhuhai) (No.311021008); the National Natural Science Foundation of China under contract (No.41941007 and No.41876220); the program of China Scholarships Council (No.201908320511).

Institutional Review Board Statement: Not applicable.

Informed Consent Statement: Not applicable.

Data Availability Statement: The data of Healy 2014, Louis 2013, Louis 2014 and Louis 2015 could be found at https:/ / doi.org/10.5683/SP2/1OIWSO (accessed on 19 October 2021). The data of Mirai 2014 could be downloaded at Japan Agency for Marine-Earth Science and Technology (2016) Data and Sample Research System for Whole Cruise Information in JAMSTEC (DARWIN): http: / / www. godac.jamstec.go.jp/cruisedata/mirai/e/index.html (accessed on 19 October 2021). ERA5 data are available at https:/ / www.ecmwf.int/en/forecasts / datasets/reanalysis-datasets/era5 (accessed on 19 October 2021). 
Acknowledgments: We thank the Office of Naval Research (ONR) for funding the cruises Healy 2014, Louis 2013, Louis 2014 and Louis 2015. We thank all scientists and staff members who contributed to the observations and reanalysis of data. We are grateful to the comments from anonymous reviewers.

Conflicts of Interest: The authors declare no conflict of interest.

\section{References}

1. Box, J.E.; Colgan, W.T.; Christensen, T.R.; Schmidt, N.M.; Lund, M.; Parmentier FJ, W.; Brown, R.; Bhatt, U.S.; Euskirchen, E.S.; Romanovsky, V.E.; et al. Key indicators of Arctic climate change: 1971-2017. Environ. Res. Lett. 2019, 14, 045010. [CrossRef]

2. Johannessen, O.M.; Bengtsson, L.; Miles, M.W.; Kuzmina, S.I.; Semenov, V.A.; Alekseev, G.V.; Nagurnyi, A.P.; Zakharov, V.F.; Bobylev, L.P.; Pettersson, L.H.; et al. Arctic climate change: Observed and modelled temperature and sea-ice variability. Tellus $A$ Dyn. Meteorol. Oceanogr. 2004, 56, 328-341. [CrossRef]

3. Overland, J.E.; Wang, M.; Box, J.E. An integrated index of recent pan-Arctic climate change. Environ. Res. Lett. 2019, 14, 1-5. [CrossRef]

4. Serreze, M.C.; Barrett, A.P.; Stroeve, J.C.; Kindig, D.N.; Holland, M.M. The emergence of surface-based Arctic amplification. Cryosphere 2009, 3, 11-19. [CrossRef]

5. Serreze, M.C.; Francis, J.A. The arctic amplification debate. Clim. Chang. 2006, 76, 241-264. [CrossRef]

6. Andersen, J.K.; Andreassen, L.M.; Baker, E.H.; Ballinger, T.J.; Berner, L.T.; Bernhard, G.H.; Bhatt, U.S.; Bjerke, J.W.; Box, J.E.; Britt, L.; et al. The Arctic. Bull. Am. Meteorol. Soc. 2020, 101, S239-S286.

7. Cohen, J.; Zhang, X.; Francis, J.; Jung, T.; Kwok, R.; Overland, J.; Ballinger, T.J.; Bhatt, U.S.; Chen, H.W.; Coumou, D.; et al. Divergent consensuses on Arctic amplification influence on midlatitude severe winter weather. Nat. Clim. Chang. 2020, 10, 20-29. [CrossRef]

8. Screen, J.A. Arctic amplification decreases temperature variance in northern mid- to high-latitudes. Nat. Clim. Chang. 2014, 4, 577-582. [CrossRef]

9. Serreze, M.C.; Barry, R.G. Processes and impacts of Arctic amplification: A research synthesis. Glob. Planet. Chang. 2011, 77, 85-96. [CrossRef]

10. Screen, J.A.; Simmonds, I. The central role of diminishing sea ice in recent Arctic temperature amplification. Nature 2010, 464, 1334-1337. [CrossRef] [PubMed]

11. Ghatak, D.; Miller, J. Implications for Arctic amplification of changes in the strength of the water vapor feedback. J. Geophys. Res. D Atmos. 2013, 118, 7569-7578. [CrossRef]

12. Yang, X.Y.; Fyfe, J.C.; Flato, G.M. The role of poleward energy transport in arctic temperature evolution. Geophys. Res. Lett. 2010, 37, 1-5. [CrossRef]

13. Pithan, F.; Mauritsen, T. Arctic amplification dominated by temperature feedbacks in contemporary climate models. Nat. Geosci. 2014, 7, 181-184. [CrossRef]

14. Bintanja, R.; Graversen, R.G.; Hazeleger, W. Arctic winter warming amplified by the thermal inversion and consequent low infrared cooling to space. Nat. Geosci. 2011, 4, 758-761. [CrossRef]

15. Esau, I.; Davy, R.; Outten, S. Complementary explanation of temperature response in the lower atmosphere. Environ. Res. Lett. 2012, 7, 044026. [CrossRef]

16. Esau, I.; Zilitinkevich, S. On the role of the planetary boundary layer depth in the climate system. Adv. Sci. Res. 2010, 4, 63-69. [CrossRef]

17. Kay, J.E.; L'Ecuyer, T.; Chepfer, H.; Loeb, N.; Morrison, A.; Cesana, G. Recent Advances in Arctic Cloud and Climate Research. Curr. Clim. Chang. Rep. 2016, 2, 159-169. [CrossRef]

18. Wood, R. Stratocumulus clouds. Mon. Weather Rev. 2012, 140, 2373-2423. [CrossRef]

19. Davy, R.; Esau, I.; Chernokulsky, A.; Outten, S.; Zilitinkevich, S. Diurnal asymmetry to the observed global warming. Int. J. Climatol. 2017, 37, 79-93. [CrossRef]

20. Davy, R.; Ezau, I. Planetary Boundary Layer Depth in Global Climate Models Induced Biases in Surface Climatology. Physics 2014. Available online: https://arxiv.org/abs/1409.8426 (accessed on 19 October 2021).

21. Holtslag AA, M.; Svensson, G.; Baas, P.; Basu, S.; Beare, B.; Beljaars AC, M.; Bosveld, F.C.; Cuxart, J.; Lindvall, J.; Steeneveld, G.J.; et al. Stable atmospheric boundary layers and diurnal cycles: Challenges for weather and climate models. Bull. Am. Meteorol. Soc. 2013, 94, 1691-1706. [CrossRef]

22. Seidel, D.J.; Zhang, Y.; Beljaars, A.; Golaz, J.C.; Jacobson, A.R.; Medeiros, B. Climatology of the planetary boundary layer over the continental United States and Europe. J. Geophys. Res. D Atmos. 2012, 117, 1-15. [CrossRef]

23. Persson, P.O.G.; Fairall, C.W.; Andreas, E.L.; Guest, P.S.; Perovich, D.K. Measurements near the Atmospheric Surface Flux Group tower at SHEBA: Near-surface conditions and surface energy budget. J. Geophys. Res. C Oceans 2002, 107, 8045. [CrossRef]

24. Tjernström, M.; Graversen, R.G. The vertical structure of the lower Arctic troposphere analysed from observations and the ERA-40 reanalysis. Q. J. R. Meteorolog. Soc. 2009, 135, 431-443. [CrossRef]

25. Shupe, M.D.; Persson PO, G.; Brooks, I.M.; Tjernström, M.; Sedlar, J.; Mauritsen, T.; Sjogren, S.; Leck, C. Cloud and boundary layer interactions over the Arctic sea ice in late summer. Atmos. Chem. Phys. 2013, 13, 9379-9400. [CrossRef] 
26. Brooks, I.M.; Tjernström, M.; Persson, P.O.G.; Shupe, M.D.; Atkinson, R.A.; Canut, G.; Birch, C.E.; Mauritsen, T.; Sedlar, J.; Brooks, B.J. The turbulent structure of the Arctic summer boundary layer during the Arctic Summer Cloud-Ocean Study. J. Geophys. Res. D Atmos. 2017, 122, 9685-9704. [CrossRef]

27. Lai, H.W.; Zhang, F.; Clothiaux, E.E.; Stauffer, D.R.; Gaudet, B.J.; Verlinde, J.; Chen, D. Modeling Arctic Boundary Layer Cloud Streets at Grey-zone Resolutions. Adv. Atmos. Sci. 2020, 37, 42-56. [CrossRef]

28. Li, X.; Krueger, S.K.; Strong, C.; Mace, G.G.; Benson, S. Midwinter Arctic leads form and dissipate low clouds. Nat. Commun. 2020, 11, 1-8. [CrossRef]

29. Bian, L.; Ding, M.; Lin, X.; Lu, C.; Gao, Z. Structure of summer atmospheric boundary layer in the center of Arctic Ocean and its relation with sea ice extent change. Sci. China Earth Sci. 2016, 59, 1057-1065. [CrossRef]

30. Esau, I.; Sorokina, S. Climatology of the Arctic Planetary Boundary Layer. Atmos. Turbul. Meteorol. Modeling Aerodyn. 2009, 3-58. Available online: https:/ / www.researchgate.net/profile/Igor-Esau/publication/285944844_Climatology_of_the_arctic_ planetary_boundary_layer/links/5704b2cb08aef745f7149564/Climatology-of-the-arctic-planetary-boundary-layer.pdf (accessed on 19 October 2021).

31. Dai, C.-Y.; Gao, Z.-Q.; Wang, Q.; Cheng, G. Analysis of Atmospheric Boundary Layer Height Characteristics over the Arctic Ocean Using the Aircraft and GPS Soundings. Atmos. Oceanic Sci. Lett. 2011, 4, 124-130.

32. Grachev, A.A.; Fairall, C.W.; Persson PO, G.; Andreas, E.L.; Guest, P.S. Stable boundary-layer scaling regimes: The SHEBA data. Bound. Layer Meteorol. 2005, 116, 201-235. [CrossRef]

33. Zhang, Y.; Gao, Z.; Li, D.; Li, Y.; Zhang, N.; Zhao, X.; Chen, J. On the computation of planetary boundary-layer height using the bulk Richardson number method. Geosci. Model Dev. 2014, 7, 2599-2611. [CrossRef]

34. Liu, S.; Liang, X.Z. Observed diurnal cycle climatology of planetary boundary layer height. J. Clim. 2010, 23, 5790-5809. [CrossRef]

35. Belkin, I.M.; Kessel, S.A. Russian Drifting Stations on Arctic Ice Islands; Springer: Dordrecht, The Netherlands, 2017; ISBN 978-94-024-1099-0.

36. Inoue, J.; Hori, M.E. Arctic cyclogenesis at the marginal ice zone: A contributory mechanism for the temperature amplification? Geophys. Res. Lett. 2011, 38, L12502. [CrossRef]

37. Sato, K.; Inoue, J.; Kodama, Y.; Overland, J.E. Impact of Arctic sea-ice retreat on the recent change in cloud-base height during autumn. Geophys. Res. Lett. 2012, 39, L10503. [CrossRef]

38. Hines, K.M.; Bromwich, D.H. Simulation of late summer arctic clouds during ASCOS with polar WRF. Mon. Weather Rev. 2017, 45, 521-541. [CrossRef]

39. Seo, H.; Yang, J. Dynamical response of the Arctic atmospheric boundary layer process to uncertainties in sea-ice concentration. J. Geophys. Res. D Atmos. 2013, 118, 12383-12402. [CrossRef]

40. Hersbach, H.; Bell, B.; Berrisford, P.; Hirahara, S.; Horányi, A.; Muñoz-Sabater, J.; Nicolas, J.; Peubey, C.; Radu, R.; Schepers, D.; et al. The ERA5 Global Reanalysis. Q. J. R. Meteorolog. Soc. 2020, 146, 1999-2049. [CrossRef]

41. Graham, R.M.; Cohen, L.; Ritzhaupt, N.; Segger, B.; Graversen, R.G.; Rinke, A.; Walden, V.P.; Granskog, M.A.; Hudson, S.R Evaluation of six atmospheric reanalyses over Arctic sea ice from winter to early summer. J. Clim. 2019, 32, 4121-4143. [CrossRef]

42. Graham, R.M.; Hudson, S.R.; Maturilli, M. Improved Performance of ERA5 in Arctic Gateway Relative to Four Global Atmospheric Reanalyses. Geophys. Res. Lett. 2019, 46, 6138-6147. [CrossRef]

43. Sorteberg, A.; Walsh, J.E. Seasonal cyclone variability at $70^{\circ} \mathrm{N}$ and its impact on moisture transport into the Arctic. Tellus A Dyn. Meteorol. Oceanogr. 2008, 60.3, 570-586. [CrossRef]

44. Zhang, X.; Walsh, J.E.; Zhang, J.; Bhatt, U.S.; Ikeda, M. Climatology and interannual variability of Arctic cyclone activity: 1948-2002. J. Clim. 2004, 17, 2300-2317. [CrossRef]

45. Chan, K.M.; Wood, R. The seasonal cycle of planetary boundary layer depth determined using COSMIC radio occultation data. J. Geophys. Res. D Atmos. 2013, 118, 12422-12434. [CrossRef]

46. Guo, J.; Miao, Y.; Zhang, Y.; Liu, H.; Li, Z.; Zhang, W.; He, J.; Lou, M.; Yan, Y.; Bian, L.; et al. The climatology of planetary boundary layer height in China derived from radiosonde and reanalysis data. Atmos. Chem. Phys. 2016, 16, 13309-13319. [CrossRef]

47. Lawrence, H.; Bormann, N.; Sandu, I.; Day, J.; Farnan, J.; Bauer, P. Use and impact of Arctic observations in the ECMWF Numerical Weather Prediction system. Q. J. R. Meteorolog. Soc. 2019, 145, 3432-3454. [CrossRef]

48. Jung, T.; Gordon, N.D.; Bauer, P.; Bromwich, D.H.; Chevallier, M.; Day, J.J.; Dawson, J.; Doblas-Reyes, F.; Fairall, C.; Goessling, H.F.; et al. Advancing polar prediction capabilities on daily to seasonal time scales. Bull. Am. Meteorol. Soc. 2016, 97, 1631-1647. [CrossRef] 